\title{
Inflation: Its Cause and Cure
}

\author{
W. PHILIP GRAMM
}

W. Philip Gramm is a professor of economics at Texas Ad-M Unitersity in College Station, Texas. Professor Gramm has published articles in variots economic foumals on topics ranging from environment to monetary and banking theory. He is a consultant to the U.S. and Canadian Governments on matters of energy and economics. Professor Gramm presented this paper at the Federal Reserve Bank of St. Louis on February $7,1975$.

$W_{\mathrm{F}}$ period of rapid inflation in the history of the United States. While we have had short periods where inflation rates have been more intense, a decade of high inflation rates is withont precedent in the history of the Republic. As an index of how severe price increases have been for the last decade, the consumer price index, which measures the price of a market lrasket of goods and services purchased by the American consmer, is ap 66 percent; the wholesale price index, which measures the price of raw materials used in the production process, is up 75 percent from a decade ago. Not only have we experienced a decade of high inflation rates, but in the last year the rate of price increase has quickened. The consumer price index is up 12 percent from a year ago and the wholesale price index is up 20 percent. These harsh economic facts suggest two questions: (1) how did we get in such a mess, and (2) how do we get out?

The first question is easy to answer. There are data on inflation which go back to the 15 th century, when gold was discovered in America, transported to Spain, and permeated the European market. Since that time there has never been a prolonged general price inflation that was not preceded by and directly related to a growth in the money supply. In our economy, growth in the money supply occurs principally when the Goverment spends more than it taxes and prints money to make up part of the deficit.

\section{The History of U.S. Inflation}

We have incurred five major inflations in the history of the United States: the Revolutionary War inflation, the War of 1812 inflation, the Civil War inflation, the World War II inflation, and the Vietnam War

Note: An carlier version of this paper was presented at Hilsdale College. Hillsdale. Michigan, in connection with a seminar sponsored by the Center for Constructive Alternatives entitled "Energy or Exhatstion: The Planet as Provider." See imminis (November 1974), pp. 1-6. inflation. All five of these inflations have had the same cause - a rapid increase in the money supply. Under the Articles of Confederation, the Continental Congress did not have the power to tax. It was therefore forced to issue paper currency to fight the Revolutionary War. The paper currency units were called Continental Dollars. You have all heard the saying "not worth a Contimental," a statement derived from the fact that when Continental Dollars were redeemed at the end of the Revolutionary War, they were redeemed at 2 cents on the dollar in gold and silver. The paper currency depreciated very rapidly because of the tremendous quantity which was issued. In essence, the Continental Congress was entering the American market and competing against private cittzens for goods and services with newly issued Continental currency, buying goods at a more rapid rate than the economy was producing them. Prices, therefore, were driven up.

In reviewing our first inflationary experience as a nation, it is important to note that at the end of the Revolutionary War the Congress established the First Bank of the United States, which systematically withdrew Continental Notes from circulation. Prices then leveled off and fell back toward their original level.

The next major inflation in American history followed the War of 1812, which was basically a carbon copy of the Revolutionary War inflation. The principal method of deriving Federal revenue was imposing import taxes or tariffs. But we were at war with our major trading partner, England, and tariffs had fallen off drastically. In order to fight the war we therefore issued large quantities of paper currency which produced a rise in the general price level. Again, however, to the credit of our forebearers, when the war was over the Congress established a Second Bank of the United States that redeemed paper currency at par. Prices leveled off and declined back toward their original level as the paper currency was withdrawn from circulation. 
The next major inflation in American history occurred during the American Civil War. The Federal Govemment ran a $\$ 1$ billion deficit, which was without precedence in history. It financed a large part of this deficit by issuing Greenback Notes. These Greenback Notes expanded the money supply by over 150 percent, and prices roughly doubled from 1860 to 1865. At the end of the war taxes were left at their war-time level and Government spending was cut back drastically. The Govermment surplus drew Greenbacks out of circulation and the Treasurer of the United States burned them. As the money supply declined prices fell off, and by 1879 we went back on the gold standard at exactly the same par value that existed in 1860 because prices had been driven back down to their previous level.

The next major inflation in American history oc. curred in World War II. The Federal Government ran a large deficit and the money stock more than doubled as the Federal Reserve monetized a part of the debt. As the Government entered the market amed with newly printed money, it drove up prices, increasing overall prices by over 60 percent during the Second World War. By the end of 1946, we were approaching a balanced budget, and by 1947 price increases had ceased. We established a period from 1947 to 1962 (except 1950) which proved to be one of the most prolonged periods of stable prices and stable economic growth in the Twentieth Century.

\section{The Current Inflation}

The next major inflation in American history occarred with the initiation of massive Government expenditures on the Vietnam War. We are today in the fith maior inflation in American history - and its source is identical to the four inflations that preceded it. The current inflation differs only by the fact that it has been carried over into a peacetime period; this is the only peace-time inflation of any real significance in the entire history of our country. Our present inflation has been caused by the fact that since $1965^{\circ}$ the Federal Government has run a $\$ 100$ billion deficit and has financed 40 percent of that deficit by printing money.

It is fundamentally important to note the difference in the impact on the economy caused by Federal financing through taxation and boktowing, as opposed to printing money. When the Govermment taxes and spends the receipts of those taxes, the ability of the private consumer to purchase goods and services is diminished by the anount of the tax. Therefore, the increase in total spetiding as a result of the increase in Govermment spending is quite small. If the Govern. ment goes onto the bond market and sells bonds, competing with private fims and private individuals for loanable funds, the competition simply arives up interest rates as Government diverts funds away from private investment projects. In this case, private spending falls by the amount that public spending increases. In the case of selling Government bonds to the Federal Reserve, which in turn gives the Treasury the capacity to write checks drawn on the Federal Reserve, there is no corresponding decrease in private spenting. So the increase in Govermment spending represents a net increase in total demand for goods and services.

There is a simple rule of thumb to follow in gauging the relation between the growth in the money stock, the growth in the economy, and changes in prices. Remember what money is used for - it is used to buy and sell goods and services and consummate exchange. We have found in economics that as the level of economic activity grows with the growth in income and commerce, the demand for money grows by a corresponding amouat. So if the economy grows at about 3 percent a year, which has been the average growth rate throughout the entire history of the United States, then the economy will absorb a 3 percent growth in the money supply with no change in prices. For example, from 1947 to 1962 the Federal Govermment ran small deficits and the money stock grew at about 3 percent per year as the Federal Reserve purchased Govermment securities in the open maket to keep interest rates low. The economy grew at about 3 percent a year so that the increase in money supply was simply absorbed in the consummation of exchange, and prices remained virtually stable for the entire period. One exception was the year 1950 . when the economic inpact of the Korean conflict was felt; the money supply grew by 10 percent and prices increased 10 percent.

Begiming in 1964 we had large increases in Fed. eral spending to finance umprecedented domestic expenditures on the War on Poverty and on Great Society programs. With the escalation of the war in Vietnam we saw the Goverument deficit rise from a fairly low level in 1964 to $\$ 25$ billion a year in 1968 . The so-called anti-inflationary surcharge imposed in 1968 had no real impact on inflation rates because Govermment expenditures grew more rapidly than tax receipts. As a result, in 1968 we ran a record peace time deficit and the money supply grew by almost 8 percent. 
In 1969, when President Nixon took office, we made the only real attempt in the whole inflationary period to stop the inflation. Beginning in Jamary, President Nixon brought the budget into balance, and the rate of growth in the money stock from Jarnary to June was zero percent. This policy worked because the rate of price increase. which was almost 6 percest on an amual bass in December and Jamury, had fallen to a 2.7 percent rate by Jume. But in April, May, and Jume the unemployment rate jumped significantly.

Unemployment rose principally because in the wage negotiations which occured in the fall of 1968, wage contracts were based on the assumption of a continuation of 5-7 percent inflation rates. This expectation was realistic, given on previons fiveyear experience. So an employer who expected the proluctivity of his workers to rise by 2 percent was willing to negotiate a 7.9 percent wage increase if he expected the price of his product to rise by $5-7$ percent. Workers, being aware of the same set of circumstances, were unwilling to accept any smalle: pay incease. If the Fedoral Govemment had continued its expansionary monetary and fiscal policy, sucl wage negotiations would have cansed no changes in the wemployment rate. But when the Federal Gowemment reversed its monetary policy in an atempt to stabilize prices. and the rate of price increase fell below 3 percent by June, the wages that had been negotiated in the fall of 1968 were two high for full employment and workers were latil off.

The Federal Goverment at this point faced a crucial decision between two options. (1) It condd reverse its monetary policy, remflate, and therefore seek to drive up prices, which would produce a fall in real watges to the point necessary to produce hill moloyment; or $(2)$ it could mantan is nonetary policy, and allow the new entruets witten in the foll of 1969 to be based on a 2.7 percent indation mte and a figher memployment rate.

In 1969 wnd 1970 the Goverment reversed its pol ioy and begm to inllate at an mereasing rate in the last six monthe of 1969 and 1970 . By Jamary of 1971 the infation rate was back up to a 6 percent amual rute and the unemployment rate was begiming to shle. Since June of 1969, when we abandoned our thly real attempt to stop the inflation, we have made no signifeant attempt to bring infation under control in this commtry. We have songht to find easier solutions to on scommic dilemma. At frost, in the second hatf of 1969, we tred a whutary approach. Then in 19:1 we went to the mandatory approal when we imposed waye and price controls and attempted to freeze prices and wages in the United States by Govermment edict.

While we in economics have a lot of data on inflation, we have even more data on wage and price controls. In fact, our first history of wage and price controls occurred 5,000 years ago when price controls were imposed in the fifth dynasty of ancient Egypt. Pericles imposed price controls in ancient Athens, and Diocletian imposed wage and price controls in ancient Rone. And from the fith dynasty of ancient Egypt to President Nixon's Phase IV price controls, all of these experiences have one thing in commonnot one has ever worked. And they do not work for a very simple reason: they freeze prices at a level where the quantity demanded exceeds the quantity supplied. They simply turn price increases into shortages and stifle the incentive to produce, therefore causing output to fall.

We have in fact produced a minor miracle in the United States in the 1970 s, in that at various times we have produced a grain and a meat shortage through Goverment policy - in a country that has the most fertile land, the highest level of capital equipnent and techology in agriculture, and the best educated famer in the world. We have produced shortages of critical mputs to the production process, sending the commery into a recession.

If one looks at what the Government says it is doing in its "anti-indation" policy, and then looks at the growth in the monetary base to see what it is actually dong, there is only one conclusion that can be drawn. That condusion is that Federal anti-ntation policy since June of 1969 has been a "fraud." Over the last 12 months the monetary base has groun at atmost an 8 percent anmul rate. Never in history has such a rate of monetary expansion faled to produce rapid inflation.

\section{Pointing the Finger of Gull}

When the Federal Goverment, in June 1969 , stopped trying to do anything about inflation it tumed its activities toward developing scapegoats in order to get Arrericans to blame their neighbor for their prob. lems. Had the scapegoat strategy not been so effective, it wonld be humorous. How does this strategy work? Well, you have all heard it. It works basically as follows. A bureancrat goes to a businessman and says, "Why are you increasing your prices?" And the businessman says, "Because our costs are rising." And then the bureatcrat says, "What is your major cost?" And the businessman says, "labor" And then the 
bureancrat concludes, "Well, labor unions cause infation." And then the same bureaucrat goes to union leaders and says, "Why are you demanding such high wage increases?" And mion leaders note that the consumer price index is up 12 percent in the past year, and that wages of hourly workers are 4 percent lower than they were a year ago in terms of real pum chasing power dollars. And the bureaucrat says, "Well, wio sets prices anyway" And the habor leaders say, "businessmen." And the bureauchat concludes, "Well, through price collusion and administered prices, businessmen crate inflation."

Then, of course, another popular version of scapegoatism was employed by former Treasury Secretary John Connally. He said, "We are all causing inflation through ou greed. We are all so greedy in competing against each other for goods and services that we are, throngh this competition, driving up prices. We have all fust got to stand back and quit being so greedy." I guess the low point in scapegoatisn was reached when Herbert Stein prononnced, just before his retirement from the Council of Eeonomic Advisers, that the American people were responsible for infation.

Picking up the scapegoat theme, Jack Andersom wrote an article in which he said high interest rates are the result of banker collusion in an attempt to drive up the interest rate to make fat profits at the public's expense. This statement, I think, showed that Jack Anderson knows nothing about banking and finance and nothing about economic history, because never in the history of the United States have we had high inflation rates which have failed to produce high interest rates, except during periods of capital rationing.

Our high interest rates over the last year, which have disrupted the long-term capital market, have been caused by imespomsible Government policy. I think it is important that we not allow bankers and businessmen to be used as scapegoats for Government failure. In fact, if one looks at nominal interest rates and the current inflation rates and attempts to draw any paralle between current interest rates, in terms of real resources borrowed, relative to real resources paid back, interest rates last year were not at historic highs, as we were told in the newspaper and on the news. They were at historic lows. We hear from Washington that Government economists marvel at record flemand in the short-term credit market in the face of record high interest rates, but if one can borrow at 12.5 pexcent on prime commercial paper and the inflation rate is 12 percent, he is paying back in real terms only 0.5 percent interest. It is indeed no marvel that the de- mand for capital in the short-term credit market has been at a record hirh, because real interest rates have been at a record low. Indeed, if the Federal Reserve had not been following an easy money policy through open market purchases of Government securities, interest rates on short-tem credit would probably have reached 15 percent last year.

\section{The Cozts of molation}

While high nominal interest rates have not disrupted the short-tem credit market, they have had a disastrous effect on the long-tem credit market, and the reason is very simple to understand. Historically, we in the United States have been blessed with fiscally responsible Government. Indeed, if you throw ont all the war years in American history, prices on the average have remained constant or fallen shightly throughout the entire history of the United States. As a result, we bave had historically low nominal interest rates. Therefore, borrowers are loathe to commit themselves over $25-30$ years to a nominal interest rate that, although it may be 2 percent or negative (in real terms) at current inflation rates, might later tum out to be an extremely disadvantageous rate if the current inflation should end. Secondly, at ligh inflation rates, funds have been diverted from their traditional chamels, whereby savings flowed into commercial banks and savings and loans institutions, and were in turn lonned ont to businesses to build new factories, to generate jobs, and to build new homes. As a result of high infation rates and interest ceilings on banks and savings and loan associations, funds have been diverted into land and commodity speculation and large Govermment bond issues.

We are all aware of the impact of inflation on income redistribution, particularly on those with fixed salaries, the old, and the poor. There is no question that this is a major cost of inflation. But an additional, more important cost is the impact caused by diverting funds from traditional channels and disrupting the link between the saver and the investor. In this way, we are today planting seeds which will yield lower economic growth rates for a decade.

Today we have a 7.1 percent unemployment rate which is highly concentrated in two industries - the construction industry and the automobile industry. As the effects of the recession in these industries spread, the unemployment rate will rise further. High interest ates, meertainty about future prices, and the availability of gasoline go a long way in explaining the plight of these industries. While the $\$ 52$ billion deficit in fiscal 1975 will stimulate these industries, most of 
the stimulation will occur in nondepressed industries. A deficit of such magnitude will assure that interest rates will be bid up as Government competes with private industry for loanable funds. If the Federal Reserve monetizes 40 percent of this deficit, as it has done over the last decade, the money supply will expand by over 20 percent and double-digit inflation will occur in 1976, even if we experience the most rapid economic recovery in American history.

\section{Goverment: The Cause of Intation}

How do we stop the inflation? Inflation has one cause and it has but one cure. And that one cure is to stow the rate of growth in the money supply. This can be accomplished only by closing the Government deficit. Our inflation has resulted from the prevalence of a banktupt (and bankrupting) idea within Government that money solves problems. If one looks at the historic growth pattern of Government spending over the history of the United States, it is very easy to discerm that within the last 15 years there has been a fundamental change within our Government. From the birth of the United States it took over 180 years for the Federal budget to grow from roughly zero to $\$ 100$ billion. It took only ten years to grow from $\$ 100$ billion to $\$ 200$ billion, and it has taken only four years for it to grow from $\$ 200$ billion to $\$ 300$ billion. Despite the fact that Federal tax collections have grown by 110 percent over a decade, over three times the rate of economic growth, the Federal Govermment has failed to live within its budget. According to Treasury Secretary Willam Simon, the Federal Government is deficit financing at such a rate that today it is ab. sorbing 60 percent of all the funds raised in U.S. capital markets.

In January 1 had the pleasure of working in Washington for my Congressman, Olin Teague, on the Energy Emergency Act. While I was there, Congressman Teague asked me if $I$ would read some of the bills that he had to vote on during the period I was working for him. I noticed that despite the fact that I make my living reading and writing, I was unable to read the bills as fast as they came in, so the stack on my kesk kept getting higher and higher. Finally, I realized that it was physically impossible for any Congressman to read the bills he had to vote on. I assert here today that no member of the United States Congress read the $\$ 25$ bilfion education act that has just become law. The sheer bulk of paperwork is so great that no effective research is being done in the Congress by those who are actually engaged in the process of making decisions in the public interest. We are experiencing an attempt by the Congress to substifute money for ideas.

Probably the best statement of the money-solvesproblems philosophy that I have ever heard was John Lindsay's statement shortly after he became mayor of New York. The gist of John Lindsay's message was as follows: people think New York City has a lot of problems, but New York City has only one problem - private affluence and public poverty. If my budget were simply twice what it is today I could solve every problem in New York City. The day John Lindsay left office his budget was over 2 times what it was the day he took office, and by every index from garbage collection to crime in the streets, New York City was a worse place to live the day he left than the day he came. And the reason is that money does not solve problems, ideas solve problems. And Govermment has had few viable ideas in 40 years.

The best personal example that I have witnessed of the bankruptcy of Govermment with regard to new and viable ideas was a call I received back in January. I was working in my office at Texas $A$ \& $\mathrm{M}$ and my secretary, who gets excited with very little provocation, came into my office and said, "Dr. Gramm, you're not going to believe this, but the President of the United States is on the telephone" And I said, "You're right, I don't believe it." Nevertheless, I picked up the phone and a very stern sounding lady said, "Is this Dr. W. Philip Gramm of Texas A \& M University?" I said, "Yes, Ma'm." She said, "Dr. Cramm, this is the White House calling."

So I sat on the edge of my chair awaiting some message - some mission from my President - and a member of the White House staff came on the phone. He said, "Dr. Gramm, your name has been given to us by some very, very important people. We think you might be the kind of person that can help us develop a new and viable energy program, a system of Government controls and subsidies, a system of Govemment and industry mutual research and project participation. And as an index of our commitment to this project we are willing to commit $\$ 20$ billion."

He went on and used every 25-cent word in the English language. When he got through, being an Aggie, I said simply, "It is a happy coincidence that out of 211 million Americans you have called the right man, because I know exactly what to do." I told him that I envisioned a system which was not going to cost a penny, but in fact would make money. It would be so productive that we could tax its output and finance Government programs on the basis of its pro- 
dnctivity. I told him that I envisioned a system whereby we would allow people to own property, and we would allow then to combine the property with their God-given talents to prodnce output. We would allow them to sell output in a free maxet so that each individual, in attempting to maximize his own welfare, would operate at maximum efficiency. And ach consumer, in attempting to maximze his own individual weltare, would economize on the things that were scarce and therefore expensive, and substitute for them things that were abundant and therefore cheap. In such a system, by rewarding production and innovation, we conth assure a maximum level of economic growth. I told him that I was basically a modest person and that I wanted him to know this was not totally my idea; that in fact if he would like a written reference, he might look at Adam Smith's Wealth of Nations, writen in 1776. And I hung up.

Well, I assumed that I would never hear from the White House again, but indeed they went to a great deal of trouble to get in touch with me. And that's how, as I expressed it, for about a two-montl period, while I didn't imvent free enterprise, I had the sole Washington distributorship on it.

\section{Conclusion}

If we are to ever put an end to spiralling prices, shortages, high interest rates and, economic stagnation, we must stop the growth of Govermment and put our monetary and fiscal house in onder. To reverse the trend of fiscal inesponsibility we need strong leadership, which is a scarce commodity in Washington today. We must resist the siren song of more and more Goverment spending and more and more Govemment controls, and stand up for the free enterprise system which has made us prosperous and free.

The hour is late. It has become quite fashonable to proclam the inevitability of the demise of our sys tem. Such a philosophy is a convenient escape. For if there is not hope, we are not obligated to do anything. In fact, there is no real reason for pessimism. We have human talents on our side. We have money and economic power on our side, and most important, we have history on our side. We have, in the American free enterprise system, the most successful economic system in the world. It has elevated us from a powerless nation, 90 pereent of whose citizens were in poverty - by any measure - at the time of the Revolution, into the greatest agricultural and industrial power on earth. So successful is our system and so high are the aspirations of the American people that we define poverty at an income level that is higher than the average income level of the world's second most powerful nation. Yet, paradoxically, this great system is nuder attack at all levels of Govermment, and is being replaced by a system which has never worked in history and which is working effectively no where in the world today, The greatest product in history is not selling for the simple reason that it has no salesman. Those withm our Government who supposedly represent our views are defending our system with an ineptitude umparalled in the history of the Republic. To reverse this trend we need but a unit of will.

I wish to tell you today that I am optimistic about the future of America, and 1 am optimistic about the future of the American free enterprise system. If we have leamed anything in the 1970 s, it is that big Goverument cannot solve problems, and that spending more of the taxpayers' money cannot turn a bad idea into a good one. Fverywhere I go in Texas and in our nation I find the American people feel a sense of helplessness. They know big Government is not working, they know something is out of kilter, but they don't know what to do about it. What we need today, more than at any time in the history of the United States, is a new wave of leadership to turn this country around. We need this leadership to fulfll the ideals and aspirations of a revolution which occurred almost two hundred years ago. In the coming struggle for the survival and the success of the American experiw ment, I call upon you as our business and civic leaders not to be merely passive observers, but to be active participants. While I cannot speak for the actions of others, in my owm case I mean not only to participate, I mean in that participation to lead.

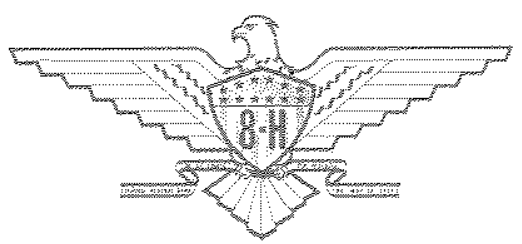

